\title{
Canberra squeezes ANU
}

\section{London}

THREE months of threat and counter-threat over the future of the Australian National University (ANU) at Canberra have been ended by a compromise announced two weeks ago by the federal minister of higher education, Peter Baldwin.

But researchers at ANU are up in arms at the proposals, and are hoping to appeal to the government over the head of the Department of Employment, Education and Training. Academics at other institutions, by contrast, tend to the belief that Baldwin's compromise is the best that ANU can hope for.

The argument revolves around the special role of ANU, created in 1946 both as a centre of excellence in research and as an indigenous means of training graduate students. ANU also incorporates a general university for undergraduate teaching (known to insiders as 'the faculties') which is small by Australian standards, with fewer than 6,000 students.

ANU researchers fear that research will be disproportionately damaged in the short run by a proposal that a percentage of research funds should be spent on externally approved collaborative research, and that the research schools' cohesiveness will be undermined by the five-year external reviews of the separate institutes' research that are now planned. And they are alarmed that the international standing of the institute will be harmed.

From the outset, research at ANU has been financed directly by the federal government, which spends more than $A \$ 200$ million a year at $\mathrm{ANU}$, reckoning that $\mathrm{A} \$ 130$ million of that is for research support. With the rapid growth of the Australian university system in the past 20 years, and the growing importance (in the past ten) of the Australian Research Council (ARC) as a source of research funds, ANU seems to have enjoyed a privileged access to funds.

Spurred by this lack of uniformity, the government last year appointed a committee under Sir Ninian Stephen, an ex-governor of Australia, to recommend an administrative framework for the Institute of Advanced Study, as the seven research schools are known collectively.

The committee's report was broadly supportive of the institute's present function, but recommended that a proportion of the institute's budget ( 5 per cent this year, rising to 12 per cent in 1998) should be earmarked for collaborative research with other Australian universities, that tenured appointments at the institute should decline to a third of the total by the end of the century and that there should be a further review of ANU in ten years.

Among other things, Stephen recommended that the John Curtin School of Medical Research, while remaining part of the academic structure of the Institute of
Advanced Study, should be provided with funds by the National Health and Medical Research Council. Baldwin accepts this proposal, which will take effect immediately.

By failing to recommend a separation between the institute and the undergraduate part of ANU, the Stephen report disappointed the federal government's declared fondness for university amalgamations (see Nature 343, 203; 1990). Prominent among these was a proposal that the faculties at ANU should be merged with the University of Canberra, until last year the Canberra College of Advanced Education.

The row over the future of ANU has been precipitated by the publication by the Department of Employment, Education and Training of an internal report by Ian Chubb, until last year pro-vice-chancellor at Wollongong University and now chairman of the Higher Education Council. Chubb's plan, which argued for splitting ANU, amalgamating all but the institute with the University of Canberra, has been hotly if predictably rejected by the council of ANU.

Baldwin's compromise leaves ANU intact, at least on paper, but the minister says that to remove "unproductive duplication and destructive competition" between ANU and the University of Canberra, each will in future have to develop a separate "educational profile" which must then be "jointly negotiated" with the federal government. But in his statement of 27 March, Baldwin said that amalgamation had "logic" in its favour, and urged the two universities to study the benefits of becoming a federal university.

On research, Baldwin proposes that 5 per cent (rising to 12 per cent) of the present budget should be transferred to collaborative projects, to be monitored for suitability by ARC. ANU academics argue that, with salaries accounting for 70 per cent of total costs, the effect on disposable research income will be much greater, reaching a half at the end of seven years.

Further ahead, each research school will be required to produce a research plan, and its progress will be assessed five years from now by a mechanism to be agreed with ARC; funds allotted to research schools then found not to be "performing" will be redirected through ARC. But ANU researchers say that merely by deciding to deal with each research school separately, the minister has robbed the Institute of Advanced Study of flexibility in redirecting its research.

Speaking from Sydney on Monday, Baldwin defended his proposals by saying that "surely it is reasonable" that ANU's research should be assessed externally, like other research. He also emphasized that "I've given them five years" (the interval before the first planned review) in which to put their house in order.

Academics elsewhere in Australia are less than enthusiastic for ANU's case. Some argue that ANU research is no longer uniformly outstanding in Australia. Others say that the research schools have neglected 'the faculties' by failing to enliven the teaching of undergraduates.

Kurt Lambeck, director of ANU's distinguished Research School of Earth Sciences, says that while performance in this respect is patchy, his own colleagues in the past two years have been teaching courses in both the physics and applied mathematics departments of the undergraduate university, partly in the hope of spotting bright graduate students. His chief regret about Baldwin's decision is that it seems to foreclose the opportunity of creating an outstanding university in Australia.

ANU's next move is likely to be to accept the parts of Baldwin's policy that coincide with the Stephen report, but to reject those going beyond it. But because the policy can be carried through administratively, without special legislation, its protests may easily be overridden.

John Maddox

\section{US APPOINTMENT \\ Eradicator of smallpox moves}

\section{Washington}

Donald A. Henderson has been officially confirmed as the associate director for life sciences at the US Office of Science and Technology Policy. Henderson, who has served since 1977 as dean of the Johns Hopkins School of Hygiene and Public Health in Baltimore, Maryland, is best known for his role in the eradication of smallpox. From 1966 to 1977 , he served as

\section{IMAGE UNAVAILABLE FOR COPYRIGHT REASONS}

Henderson - filling a vacancy.

chief medical officer of the Smallpox Eradication Program of the World Health Organization, directing some 700 advisers and 200,000 workers in 69 countries in wiping out the disease.

The Office of Science and Technology Policy advises the President on science policy and also coordinates science programmes among various executive agencies. The position of associate director for life sciences has been vacant for more than a year, since James Wyngaarden resigned.

Robert Pool 